\title{
Pathophysiology and Treatment of Urolithiasis in Unani Medicine
}

\author{
I Mohammed Tabarak Hussain*, Ghufran Ahmed**, \\ Nasreen Jahan ${ }^{* * *}$, Mehar Adiba***
}

(Received 1 April 2014; revised 19 January 2015)

\begin{abstract}
The Greek philosopher and physician Hippocrates (460-377 BC) postulated the theory of humoral medicine, upon which the Unani system of medicine is based. Rhazes writes in $A l-H \bar{a} w i$ that the process of stone formation in any part of the body is secondary to the entanglement of lesdār mawād (thick and viscid morbid matter) in the organs and the inability of the human body to expel the matter. This morbid matter retains in the organs, and secondary deposition takes place over time. Harārat evaporates rutūua āt from the matter and thereby hardens forming a stone. The renal calculi are soft, small and usually reddish in colour whereas the bladder stones are hard, large and sandy white or black in colour. The explanations given by Sabit bin Qurra (901 AD), al-Rāzī (932 AD), Ibn Sīnā (d. 1037 AD) and Ibn Zuhr (1162 AD) about the formation of stones, are basically same. In Greco-Arab medicine, known in India as Yūnānī or simply as Unani medicine, the atibb $\bar{a}^{\prime}$ (physician) evaluates nabd (pulse), baul (urine), and barāz (stools) for diagnosis of diseases. The line of treatment for both renal and bladder calculi are almost similar. Several single and multiple drug formulations have also been described for treatment of urolithiasis.
\end{abstract}

Key words: Pathophysiology, Treatment, Unani Medicine, Urolithiasis

\section{INTRODUCTION}

Unani medicine originated in Greece. The Greek philosopher and physician Hippocrates (460-377 BC) postulated the theory of humoral medicine, upon which the Unani system of medicine is based. Hippocrates contended that there are four humors (akhlāt plural of khilt)-dam (blood), balgham (phlegm), safrā (yellow bile), and sauda (black bile). These four humors have different colors, appearances, compositions, physical properties, and proportions in a body that is in homeostasis. Hippocrates described health as the state in which all four humors are in correct proportion and composition to one another. Thus, sickness is thought to occur when any of these humors is deficient or overabundant in the body or undergoes a change in its composition or physical properties. Mizāj, or temperament, indicates the state of equilibrium among the four humors. Therefore miza $j$ is of four types and qualified as follows: harārat (hot), burūdat (cold), yabusat (dry), and rutūbāt (moist) (Isrā' $1 \overline{1}, 1981$ pp.95-99). In short, any alteration in the properties or deviation from the homeostatic proportions of the humors, disturbs body temperament leading to diseased conditions.

The Middle East had a pivotal role in the history of urology (Haddad, 2002). Three important figures in medicine during the Middle ages were of Persian origin: Muhammad Ibn

\footnotetext{
* Department of Ilmul Advia, HMS Unani Medical College, Tumkur, Karnataka. Email: imdth@rediffmail.com (Corresponding author)

**Department of Ilmul Advia, AKTC, Aligarh, Uttar Pradesh

***Department of Ilmul Advia, NIUM, Bangalore, Karnataka
} 
Zakariyā Rāzī (865-925 AD), 'Alī Ibn al- 'Abbās al-Majūsī (930-994 AD), and Abū 'Alī al-Husayn Ibn 'Abdullah Ibn Sīnā (981-1037 AD), who are known to the West as Rhazes, Haly Abbas, and Avicenna respectively (Ardalan, 2007, pp.34133421). Avicenna's Canon of Medicine is considered to be the first medical textbook and has been used by Western scholars. William Osler wrote, "[Avicenna's] Canon was a medical bible for a longer period than any other work." Part nineteen of the third book and portions of the first book of Avicenna's Canon of Medicine address the urinary tract and urological diseases (Madineh, 2008 pp. 284-293).

\section{Pathophysiology}

\subsection{Mechanism of Formation}

In Kāmilus Șanā', Ibn Abbās al-Majūsī mentions that renal calculi and gravel are due to shadìd harārat (excessive heat) and khilt ghalìz (sticky, viscid humor) in the body. The shadìd harārat causes the moisture within the khilt ghaliz to evaporate, and the dried constituents form stones over a period of time. The formation of renal calculi or gravel depends on the viscosity of the khilt ghaliz following interaction with shadid harārat. A moderate increase in viscosity results in the formation of gravel, which is not as hard as renal calculi and is slowly excreted from the urinary tract along with urine and forms sediments in the urine. However, a significant increase in viscosity results in the formation of very hard and large particles, which are not as readily excreted and combine to form renal calculi. The persistence of shadìd harârat in the body and thus in the kidneys leads to hardening of the stones, when stones retain in the urinary tract for a long period of time (Al-Majūsī, 1889, Vol 1, p.525).

Ibn al-'Abbās al-Majūsī also notes that the formation of hisșāt-i mirārāh (bladder calculi) is similar to that of renal calculi. Bladder calculi are commonly seen in adolescents because they are more prone to ratab mizāj (moist temperament), are more physically active, and consume an improper diet, whereas in adults bladder calculi are common in those who consume heavy diet, or ghalīz ul kaimūs ghidhā (Al-Majūsī, 1889, Vol 1, p. 525).

According to Galen, renal stones are formed when rīh (gaseous matter) is trapped in the spaces of the kidney and consolidates into hard substances. Another cause of renal calculi is ulceration of the kidney, in which pus accumulates and solidifies, thereby forming renal stones or at least establishing a nidus for the formation of stones. Avicenna contends that the persistence of "morbid matter" in the urinary tract is instrumental in the formation of ghalīz māddā (viscid matter). Morbid matter is formed when a heavy diet is consumed; foods in such a diet include thick milk, paneer (cheese), fried meat, rice, flour and fruits that are not easily digested. These foods produce a thick, viscous matter in the body, especially in the state of du'f quwwat-i hadima, or weak digestive power, thereby forming khilt ghalīzand $r \bar{h} h$, which accumulate in the urinary tract. These accumulations remain in the kidney for a long time, as the kidney has weak expulsive power, which is further diminished in the conditions such as $s u-i$ mizāj kulliya a (abnormal temperament of the kidneys), warm-i-hār kulliyā or inflammation due to heat in the kidneys, or qarāh-i kulliy $\bar{a}$ (ulceration of the kidneys). Harārat causes this morbid matter to transforms into gravel, which are either expelled through the kidneys or retained and converted into stones (Kabiruddin, 2003, Vol 2 pp.1201-1220).

Rāzī writes in Al-Hawī that the process of stone formation in any part of the body is secondary to the entanglement of lesdār mawād in the organs and the body's inability to expel the matter readily. This matter remains in the organs, and secondary deposition takes place over time. Harārat evaporates rutūbāt from the matter and thereby forms a stone (Rāzī, 2002, pp. 92-93). 


\subsection{Age and Gender}

Unani medical literature holds that renal calculi are more common in middle-aged individuals, and bladder calculi are more common in adolescents. In middle-aged people, harārat (heat) is less and khilt balgham (sticky, viscous phlegm) is more. Furthermore, the digestive power of middle-aged is weak. The lumen of the urinary tract becomes narrow due to increased burūdat (cold). As a result, smaller constituents pass through the kidney and into the ureter and bladder, but larger constituents retain in the kidney spaces. Harārat in the kidney is sufficient to dry the constituent and facilitate the formation of stones.

In adolescents, the bladder calculi are usually large because they are physically more active, consume an improper diet frequently, and do not take rest after eating. In adolescence, the spaces in the kidney and urinary tract are large and open; thus, urine, along with its constituents, easily passes from the kidney to the bladder. The harārat-i-ghariziya $\bar{a}$ (innate heat) is present more in adolescents, and quwwat-i dâfi 'ya (evacuating power) is also stronger in comparison with other age groups. Therefore, all the morbid matter is expelled out from the kidney along with the urine easily. In adolescence the urethral orifice and other excretory organs are small, and the constituents of the urine that are smaller in size are excreted out easily, but larger constituents remain back in the bladder. The harārat (heat) of the bladder acts on and dries up these constituents, thereby forming bladder stones. In case of young adults since their organs are well developed, they have more harārat compared to rutūbāt in the body and all the systems i.e. digestive, excretory etc are functionally excellent. They maintain healthy dietary habits, even if morbid matter gets accumulated this is expelled out easily. In the case with females, the urethral orifice is large which facilitates easy expulsion of larger morbid matters present in urine; hence they are less prone to urolithiasis (Al-Majūsī, 1889, p.525).
Ismā'‘̄l Jurjānī in his book Dhakhirā-iKhwārazm Shāhī states that urolithiasis is common in children, middle age and less common among elders. In children and elderly stone is formed in the bladder while in adults, in the kidneys. The causes mentioned by Jurjānī are that the orifices and vessels are wide in older age group whereas in case of adult they are small and tight. In case of females since they have a wider urethra compared to males, the accumulated morbid matter is easily expelled whereas in case of males the morbid matter gets accumulated and is not easily expelled. The cause for bladder stone in children is that the quwwat-i dāfi 'ya (evacuating power) is more powerful in children hence after digestion the matter is passed on to the kidney quickly and then to the bladder. Moreover, the urine of children is thick, viscid due to improper eating habits; urethral orifice is small and the salt content in the urine is more. The presence of ghalīz rutubāt (morbid liquid matter) acted upon by the harārat (heat) causes evaporation of liquid leading to solidification of its constituents. In children the urine contains lots of sediments and the harārat (heat) is also relatively more which encourages the solidification of sediments. The main causes leading to stone formation are the excess of ghalīz (thick in consistency) and lazūj rutūbāt (viscid liquid) which is formed due to ghalīz ghidhā (morbid diet). Heavy diet such as beef, camel's meat, fried egg, nan, wheat, milk, rice, paneer, fālüda, turanj, guava and alcohol are the important and indirect cause of stone formation. Irregular food habits, abstinence from sexual activity especially when the liver and GIT are weak and excessive harārat in the kidney are also responsible for stone formation (Jurjānī, 1903, pp.245-255).

According to Hakīm 'Āẓam Khān, stones are often formed in kidneys of obese people, while in the bladder of lean people. In old age renal calculi are more common while in children and young people bladder calculi are more often found. Calculi are often formed in children because of 
excess and untimely eating habits, increased harārat (heat) due to growing age; their ureter are stiff and spaces are not wide open while in old age the main cause of calculi is the weakness of quwwat-i hạdimā (Digestive power) (Kabiruddin, 2003 Vol 2, pp.1201-1220).

According to Ibn Sīnā there are differences in the constituents of renal and bladder stones. The renal calculi are soft, small and usually reddish in colour whereas the bladder stones are hard, large and sandy white or black in colour (Kabiruddin, 2003 Vol 2, pp. 1201-1220). A group of atibb $\bar{a}$, (Unani physicians) have mentioned that calculi formation takes place even in intestines, colon, liver and joints. Though the sediments differ in colour, sometimes they are dark yellowish, sometimes red, sometimes muddy, and sometimes similar to the colour of seeds of pomegranate (AlMajūsī, 1889, Vol 1, p. 525).

The explanations given by Sābit bin Qurra (901 AD), Al - Rāzī (932 AD), Ibn Sīnā (1037 AD) and Ibn Zuhr (1162 AD) about the formation of stones were basically similar, that heavy food stuff, dairy products and poor kidney function could be the cause. They thought outflow obstruction, familial tendency also the causes. All these explanations correlate with the modern concept of urolithiasis (Rāzī, 2002, pp.376-378).

The mechanism of calculi formation in the urinary tract is still poorly understood. A few possible conditions that promote urolithiasis are increased concentration of crystalloids in urine, change in the physico-chemical state of urine and changes in the wall of the collecting system.

The urine contains crystalloids such as uric acid, urea, sodium, potassium, ammonium, magnesium, calcium carbonate, cystine etc and colloids such as mucin, chondrotin etc. The crystalloids are held in solution by the protective action of the colloids. Under certain circumstances these crystalloids become precipitated, at the same time colloids are also modified regarding their solvent action and acquire a kind of adhesive property. Thus the precipitated crystals are bound together by the altered colloids to form stones. Alteration in the $\mathrm{pH}$ of urine, urinary infection and increased content of mucoprotein in urine are those conditions which tend to alter the physicochemical nature. A few recognized factors which help to produce changes in the wall of collecting system are vitamin A deficiency, theory of Randall's plaque and urinary stasis (Mohan, 2000, p.4; Biswas, 1997, pp. 646-647; Dey \& Dey, 2003).

The known physiochemical features of urolithiasis are readily divided into four interrelated subjects: the driving force (supersaturation), nucleation, the growth of crystals and particles, and aggregation. Supersaturation with respect to the salts that stones will or do consist of gives rise to the thermodynamic driving force for the formation of stones. Nucleation is the initial event in a phase transformation (e.g., stone-salt precipitation). A slurry of crystals in a supersaturated solution will increase in size and under appropriate conditions will aggregate, in which case the particle size distribution is not the same as the crystal size distribution. As the size of particles diminishes, the effect of adhesion relative to gravitation rapidly becomes dominant (Finlayson, 1978).

\subsection{Signs, Symptoms, and Diagnosis}

In Unani medicine, the ațībb $\bar{a}$ ' (physician) evaluates nabd (pulse), baul (urine), and barāz (stools) in order to diagnose disease, and when urolithiasis is suspected, the urine is carefully examined to make the final diagnosis. Patients are advised to collect urine overnight in a clean container that must be protected from contaminants. On the following day, the urine is discarded without disturbing any sediment in the container. Red or yellow sediments are diagnostic of urinary stones or gravel (Kabiruddin, 2003, Vol 2, pp. 1201-1220). 
When urine transforms from thick and viscous to clear and watery, the morbid matter is accumulating in the kidneys and thereby causing stone formation. When black-colored urine appears in the absence of systemic disease or pain in the lumbar region accompanied with abdominal colic, then kidney stones are thought to have formed. If the pain radiates from the loin towards the pubic area, it is assumed that the calculi are descending in the ureter. Alleviation of pain in the lumbar region suggests that the renal calculi have reached the bladder. Signs and symptoms of bladder calculi are dysuria, incomplete voiding of urine, irritation at the root of the urethra, and pruritis over the genitalia, which compels the patients to rub his hands over the pubic region. The gravel and sediments of bladder calculi are muddy or white (Jurjāni 1903, pp. 545-555).

According to Ibn Sīnā, renal calculi are soft, small, and usually red in colour, whereas bladder calculi are hard, large, and sandy white in color (Kabiruddin, 2003 Vol 2, pp. 1201-1220). Renal calculi cause heaviness in the lumbar region when the intestines are full. The color of urine will be yellow-red (Arzāni, 2002, pp. 182-187). Signs and symptoms of urinary calculi are presence of sediments in the urine, lower back pain, numbness in the legs, and dysuria. The sediments may be yellow, red, or brown, and may resemble pomegranate seeds (Al-Majūsī, 1889, Vol 1, p.525). Urinary disturbance accompanied by pain in the loin region during micturation, nausea, and constipation suggests that calculi are present in both kidneys (Rāzī, 1991, pp. 376-378).

\section{USūL-I ' ' ILĀJ (Principles of Treatment)}

\section{Unani Pharmacotherapy for Urolithiasis}

The treatment of urolithiasis in Unani system of medicine is in two steps:-

1) Symptomatic treatment given during the attack of pain or renal colic.

2) Curative treatment after the symptoms of pain subsides (Kabiruddin, Vol 1, pp. 168-170).

\subsection{Symptomatic treatment:}

Nutūl (irrigation) and massage with roghan (oil), and use of dimād (paste) and qairuti (poultice) on the affected part is useful in this condition but these measures must be done in controlled manner so that "Quwwat-i dāfiyā"(evacuating power) should not get exhausted, then "Mufattit" (lithotryptic) and "Mushil" (Purgative) drugs can be used.

For the purpose of "nutu $\bar{l}$ " (irrigation) the following drugs can be used:-

Nuṭūl (Irrigation): Gul țesu - (Flowers of Butea monosprema) 2 Tola $(1$ Tola $=12 \mathrm{gm}$ approx $)$; Persiaoshān-(Adiantum capillus veneris) 2 Tolā; Kabootar ki beet- (Excreta of pigeon) 1 Tolā; Tukhm-i Khayarain- (Cucumis sativus) 1 Tolā, Tukhm- i Kharpaza- (Cucumis melo) 1 Tolā, soak all the drugs in water, decoction prepared and used as numūl (Kabiruddin, Vol 1, pp. 168-170).

Massage: 'Arq ' ajīb 5 drops with Sirkah (vinegar) 2 Tolà (Kabiruddin, Vol 1, pp. 168-170).

Qairuti (poultice): Dough prepared from Arad karasna (Pisum sativum)( Kabiruddin, Vol 1, pp. 168-170).

$\bar{A} \boldsymbol{b z a n}$ (sitz bath): Decoction prepared using Gokhru (Tribulus terrestris), Babuna (Matricaria chamommila), Aklilul mulk (Mellilotus officinalis), Karafs (Apium graveolens), Karnab (Bressic oleraceae), Barg khitmī (leaves of Althaceae officinalis), Persiaoshān (Adiantum capillus veneris)( Al Majūsī, 1889, Vol 1, p. 525).

Orally: Shīr bādiyān (milky juice of Foeniculum vulgare) $5 m \bar{a} s h \bar{a}$ (1 māsh $\bar{a}=1$ gm approx), Shīr Tukhm karafs (milky juice of Apium graveolens) 2 māshā, Arq bādiyān (decoction of Foeniculum vulgare) 12 tolā, 'Arq gulāb (decoction of Rosa damascus) 12 tolā, Gulqand (compound preparation of Rose petals and honey) 2 tola and use orally (Kabiruddin, 2003 Vol 2, pp.12011220).

After the episode of colic is managed successfully, the next step would be towards 
lithotripsy and its expulsion from the body (Kabiruddin Vol 1, p. 525).

The Ușull-i 'Ilāj of renal stone as mentioned by Hakim 'Azam Khān is to remove the ghalīz $m \bar{a} d d \bar{a}$ (morbid matter) so that further stone formation can be prevented. Then drug therapy is given to the patients to expel the already formed stones (Kabiruddin, 2003 Vol 2). Rāzī also states about $U s \underline{u} l-i$ 'Ilāj that, cause must be treated first and the morbid matter accumulated in the body must be removed. Diet responsible for stones formation must be stopped (Rāzī, 2002, pp. 92-93). The initial step in evacuating the morbid matter is to give emetics and mushil (purgative) to help remove the morbid matters. The emesis serves dual purpose, firstly it is an instant measure and can be repeatedly given and secondly it can be used to expel the entire morbid matter from gastrointestinal tract (GIT) in a shorter time. Whenever mushil is given care should be taken that harärat in the body is maintained at optimal level. If harārat is however at a relatively low level then mushil of low potency should be prescribed. The stomach should be strengthened by some muqawwi mi'dah drugs for easy digestion. Moderate but regular exercise and massage should be advised (Jurjānī, 1903). The line of treatment for both renal and bladder calculi are almost similar. Heavy and fatty diet, unhygienic water should be avoided. If nuskha khalal-i shikam is to be advised then moderate exercise and massage of the back and loin must be advised. Among the preventive measures, drinking of cold water during meals and use of Katān (Linum usitatissimum) mattress to sleep has been especially mentioned to be avoided (Kabiruddin, 2003Vol 2, pp. 1201-1220).

\section{Drugs Beneficial in Urolithiasis}

In Kitābul Kulliyāt, Ibn Rushd writes that the statements of many atibb $\bar{a}$ that, the drugs used as mufattit- $i$ hissāt (lithotryptic) must have mild degree of harārat because severe degree of heat makes substances harder, such as the harārat-i $\operatorname{ghar} \bar{i} b \bar{a}$ (abnormal heat) responsible for the formation of renal stones. Hence the amount of harārat in the drugs used as lithotryptic must be less than that required for the formation of stones. The principle used is, any substance or morbid matter which is under the influence of harärat (hot) and yabusat (dry) can be correct by burūdat (cold) and rumubāt (moist). Hence the temperament of drugs to be used for the treatment of urolithiasis must be less hot comparatively. These mild degree drugs bring equilibrium in the morbid matter or substance and the harārat- $i$ ghariziya (normal heat) expels them out of the body. The drugs beneficial are halyun, chana, $b \bar{a} d \bar{a} m$ etc. It is also possible that these drugs act due to their constituents and their characteristic features (Ibn Rushd, 1987, pp. 224-227).

Drugs which are used to expel the urinary stones must be talkh (bitter) in taste, not very hot, and have the property of taqtī (cutting, making into small bits). Drugs used for bladder calculi must be slightly hotter than those used for renal calculi. However few drugs are used which act because of their mufattit (lithotryptic) property and not because of hot or cold temperament. There are some drugs which are useful in renal calculi than in bladder calculi such has Hajrul yahūd. Few drugs are beneficial in both bladder and renal calculi. Some drugs do not have the property of $n u z j$, but a few are mufattit as well as have the property of nuzj like habbul qil qil. Mudir-i baul (diuretic) drugs also have mild degree of harārat, which helps the kidneys to absorb the liquid matter. All those drugs which are tez act as diuretics such as Karafs (Apium graveolens), Bādiyān (Foeniculum vulgare), dūqū (Peucedanum grande) etc. (Ibn Rushd, 1987, pp. 224-227).

\section{Nuskhejaath: Mufrad (Single) Drug Formulations Beneficial in Urolithiasis}

\section{1) Formulation}

Ajwāin (Carum copticum) 3 māshā (1 māshā = 1 gm approx) 
Tukhm- $i$ karafs (seeds of Apium graveolens) 3 $m \bar{a} s h \bar{a}$

Mișrī $3 m \bar{a}$ shā, all the three drugs must be powdered and sieved, then 3 māshā must be consumed after food twice a day (Kabiruddin , Vol 1, pp. 168-170).

\section{2) Formulation}

Tukhm-i kharpiza (seeds of Cucumis melo) 17.5 $m \bar{a} s h \bar{a}$

Tukhm-i khayarza (Cucumis melo var utilissimus) $17.5 m \bar{a} s h \bar{a}$

Tukhm-i khayar (seeds of Cucumis sativus) 17.5 $m \bar{a} s h \bar{a}$

Tukhm-i karafs (seeds of Apium graveolens) 7 $m \bar{a} s h \bar{a}$

Rāziyāna (Feoniculum vulgare) 10.5 māshā

Crystals present in Asfanaj (Spinacia oleracea) $10.5 m \bar{a} s h \bar{a}$

Abkinasokta (charred Spinacia oleracea) $10.5 m \bar{a} s h \bar{a}$, these drugs have to be powdered and sieved through a fine silk cloth. The fine powder thus obtained has to be consumed $10.5 \mathrm{ma} s h \bar{a}$ along with sikanjabin (preparation of vinegar and honey) (Al-Majūsī, 1889 Vol 2).

\section{3) Formulation (When no harārat is already present)}

Tukhm-i Khayarza (Cucumis melo var utilissimus)

Tukhm-i karafs (seeds of Apium graveolens)

Anisūn (Pimpinella anisum)

Tukhm-i karafs kohi(seeds of Petrosillium crispum)

\section{Taj (Cinnamomum cassia)}

Sambul (Nordostachis jatamansi)

Dārchīn̄i (Cinnamomum zeylanicum)

Kulthi (Dolichos blepharis), all these drugs in equal quantity, amounting to 1 part of the formulation and Aqarqarha (Anacyclus pyrethrum), Jundbedaster (Castar beaver)

Farbūn, all these drugs in equal quantity, amounting to 4th part of the formulation.

After powdering and sieving the powdered drugs through fine silk cloth, 4 Māshā is taken and a decoction is prepared using water. This decoction is to be given along with sikanjabin (preparation of vinegar and honey) (Al-Majūsī, 1889, Vol 2, pp. 464-468).

\section{4) Formulation ( When there is mild harārat present)}

Gokhru (Tribulus terrestris)

Kulth̄̄ (Dolichos blepharis)

Hajrul yahūd (Jews stone), all these drugs are taken in equal quantity, amounting to 1 part of the formulation.

Maghz-i Tukhm-i Khayarza (Cucumis melo var utilissimus)

Magzi Tukhm- $i$ Kharpiza (Cucumis melo)

Tukhm-i Rāziyāna (Foeniculum vulgare)

Post bīq karafs (Apium graveolens), all these drugs in equal quantity, amounting to 1 part of the formulation.

After powdering and sieving the powder through fine silk cloth, $7 m \bar{a} s h \bar{a}$ is given along with decoction which is prepared using with Rāziyāna and Persiaoshān. This decoction is to be given along with sikanjabin (preparation of vinegar and honey) (Al Majūsī, 1889 Vol 2, pp. 464-468).

\section{5) Formulation (especially for renal stones)}

Tukhm-i Kharbūz (seeds of Cucumis sativus)

Tukhm-i Karafs (seeds of Apium graveolens)

Tukhm-i Turb (seeds of Raphenous sativus)

Zìra (Carum carvi)

Ajwāin (Carum copticum) 
Badām talkh (Prunus amygdalus var.amara) all the drugs are taken in equal quantity, powdered and sieved through fine silk cloth, $3 m \bar{a} s h \bar{a}$ is to be taken along with decoction is prepared using Persiaoshān (Jurjānī, 1903, pp. 545-555).

\section{6) Formulation (clinical study)}

Hajrul yahūd (Jews stone) $5 \mathrm{gm}$

Sang-i sarmāhī (Stone of fish) $5 \mathrm{gm}$

Kulthī (Dolichos blepharis) $7 \mathrm{gm}$

Kharekhask (Tribulus terrestris) $7 \mathrm{gm}$

Jawakhar (Pearl ash) 7 gm

Khayarain (Cucumis sativus) $7 \mathrm{gm}$, prepare a fine powder of all the drugs, mix them thoroughly, then use $7 \mathrm{gm}$ along with Sharbat àlubālu 35ml and Māj ' 'ūn Aqrab 7 gm twice in a day for 1 month (Farooqi, Sheikh, Muqaddam, 2012, pp. 15-18).

\section{7) Formulation (clinical study)}

Hajrul yahūd (Jew's stone) $10 \mathrm{gm}$

Sang-i saremāhī (Stone of fish) $10 \mathrm{gm}$

Habbul qilt (Dolichos blepharis) $10 \mathrm{gm}$

Namak Turb (Raphenus sativus) 20 gm, a fine powder of all the drugs is prepared and mixed thoroughly, $3 \mathrm{gm}$ is given thrice a day for 75 days (Kumar, 2011).

\section{Murakkab (Compound) Formulations}

Māj 'ūn Hajrul Yahud, Māj 'ūn Aqrab (Ibn Rushd, 1987, p. 224-227) are the compound Unani formulations indicated in the treatment of kidney stones.

The translation of "The Hidayat of AlAkawayn̄" by Mohammad R., Ardalan and coworkers on the presentations of the urinary stones, it is stated that when the stone enlarges in the kidney it obstructs the urine flow, causes intolerable pain and may lead to mental confusion from pain. Each occasion of the pain is called an episode. During the episode of pain the patient should sit in a tub of warm water in which leaves of cabbage (Brassica oleraceae), leaves of marsh mallow (Althaea officinalis), chamomile (Anthemis nobilis), dwarf yellow (Astragalus hamosus), fenugreek (Trigonella foenum graecum), flax seeds (Linum usitatisimum), seeds of mingwort (Artemesia absinthum) and star thistle (Centaurea calcitrapa) have been brewed. After getting out of water tub, the back of the patient should be massaged gently with oil of wall flower (Cheiranthus cheri), and then patient should jump up and down on one foot, or ride a horse trotting in place or climb fast down a ladder until the stone comes out. The single drugs used for the expulsion of urinary stone are Jew's stone (Lapis judaicus) grinded in clean water and three Deram-sang (1 Deram-sang $=12.5$ gram) of it is consumed, root of Cumin (Cuminum cyminum), Scholopendrium, seed of Caper (Capparis spinosa), Cappilaire (Adiantum capillus veneris), round Cyperus (Cyperus rotundus), root of star thistle (Centaurea calcitrapa), Caraway (Carum Carvi), seeds of melon (Cucumis melo), seeds of Cucumber (Cucumis sativus), seeds of pentophyllum (Gynostemma pentaphyllum) and beet root (Beta vulgaris) concentrate. These drug are the first line of treatment drugs. Ground pine (Teucrium chamaepitys), dittany (Marrubium pseudo dictamnus), herb ivy( Ajugaiva), decoction of black pea (Lathyrus niger), Indian djatrah, crown of the root of agrimony (Agrimonia eupatoria), seeds of raddish (Raphanus sativus) and these drugs are stronger, strongest of them is beetle (Cantharides), but care should be taken as it could lead to bladder ulceration. Those drugs that dilate the urinary duct like the seeds of melon, cucumber, white cucumber (Cucumis anguini), seeds of marsh mallow, seeds of sweet squash (Cucurbia maxima) are also recommended (Ardalan, Shoja, Tubbs and Eknoyan, 2007, pp. 3413-3421).

Hippocrates recognized and described stone disease but also said "I will not cut persons laboring under pain but will leave such procedures 
to be done by the practitioners of the craft" (Salam, 2003, p. 5).

Masīhī states, "In case of obstruction of urine due to a calculus and when no other option is available except for surgery, bladder calculus can be removed by applying incision" (Al-Masīịī, 1986, pp. 235-238).

Abū al-Qāsim al-Zaharāwī (936-1013 AD) in his medical encyclopaedia "Altasriyfliman ajiza anialta lify" has described over 200 surgical instruments with illustrations and method of their manufacture. In urology he described the drilling on urethral stones and the operation of vaginal lithotomy. Ibn Sīnā introduced the technique of instillation of medication into the urethra. Ibn 'uhr known to the west as Avenzoar (1091-1162 AD) also described the diamond tipped lithorite in his book "Al-Taysīr" (Haddad, 2002, pp. 243-257)."

\subsection{Surgery}

According to Mașīhī pre operatively "Huqnä" (enema) must be given to clear the intestines. Then the patient must be advised to jump for a few times, the assistants are asked to hold the patient by the arms and hang him so that the calculus rolls down into the bladder till the opening of urethra. Make the patient sit in such a position that his hands are placed on the thighs and the bladder is directed downwards. In case of children per rectal $(\mathrm{P} / \mathrm{R})$ examination must be done using forefinger, in adults and elderly using middle finger. The fingers must be lubricated using Roghan Banafsha (oil extracted from Viola odorata). Once the calculus is felt over $\mathrm{P} / \mathrm{R}$ it must be pushed down towards the orifice. Advise the assistant to hold the genital organs upwards, to prevent injury due to incision. Apply incision from the anal orifice to the testicles in such a way that it is not exactly in the centre but towards the left, wide above and narrow below, to prevent damage to sexual organs. Do not remove the fingers from the anal orifice while giving incision. Sometimes because of the pressure of finger from below the calculus may come out through the incision. If the calculus is near the incision, then manipulate it with hand and remove but if it is far from the incision it should be removed using blunt forceps. In case there are multiple calculus, then they must be removed one by one. In case the calculus is large in size then instead of increasing the size of the incision, the blunt forceps must be used to crush the stone and remove the stone. In case of haemorrhage powder of phitakrī (Alum) should be applied. After the surgery is completed powder made using Kundur (Boswellia serrata ), Dammul aqwain (Dracena cinnabari) and sibr (Aloe barbadensis ) should be applied on the wound. The patient must be advised to sleep in the lateral position without separating the thighs for 3 days. The dressing must be moistened using roghan gul (oil extracted from Rosa damascus). After 3 days remove the dressing and apply marham aswad and repeat the dressing in the same manner without separating the thighs. Mașīhī also states that the procedure is easier in children than in adults and difficult in females (Al-Mașīhī, 1986, pp. 235238).

\section{Conclusion}

The Unani philosophers and physicians described diseases, their causes, signs and symptoms and their treatment based on humoral theory. The concept of health and disease was described in the light of humors and their kaifiyāt (qualities) and not superstition or merely observations. So, Unani medicine can be considered as a rational medicine. However, its rationality does not comprise molecular descriptions as in modern medicine, but on a scheme of supra-physical level of man and drug i.e. the kaifiyāt (qualities) of hot/ cold and dry/ wet. Secondly, as the clinical predictions made on the basis of this scheme are generally validated by empirical testing, so it is proved that the Unani principles of kaifiyat $t$ are in accordance with reality. So, Unani medicine should be practised on the basis of its fundamental principles. The modern 
medicine may not agree with principles of Unani but it could certainly benefit from the empirical descriptions and correlations made on the basis of those principles. Since, the empirical predictions have been and are tested practically in a rigorous manner they could be accepted and included in the classical texts. Perhaps this approach is responsible for its practical existence even today. In this paper we have attempted to put forth the Unani concept of Urolithiasis, which to a larger extent holds good in the present times also.

\section{ACKNowledgments}

We wish to thank Dr. Salma Jabeen for her contribution towards the paper with respect to grammatical correction and editing of this paper. We also extend our gratitude to Dr. Anand N. Bosmia (Section of Pediatric Neurosurgery, Children's Hospital of Alabama, Birmingham, AL, USA) for his contribution towards editing the manuscript. We shall always remain grateful to Dr. R. C. Kapoor for his guidance, but for him this paper could not be possible. Thanks are also due to Professor S.M.R. Ansari for inserting titles and the diacritical marks for technical terms and for going through the paper very thoroughly.

\section{BiBLIOGRAPHY}

Ardalan, Moḥammad, R., Shoja, Moḥammadali M. Tubbs, Shane R. and Eknoyan, Garabed. Diseases of the kidney in medieval Persia- The Hidayat of AlAkawayni. Nephrol Dial transplant. 22 (2007): 34133421.

Arzāni, Hakīm Muhammad Akbar. Mīzān-i libb (Trans. in Urdu by Hakīm Kabiruddin). Idare Kitab al-Shafa, Delhi, 2002.

Biswas, Sunil. Essentials of Pathology. New Central Book Agency (P) Ltd, New Delhi,1997.

Dajani, A. M. Urinary Stone Disease in Arabian Medicine. Foundation for Science, Technology and Civilization, Manchester, UK, 2002.

Dey NC and Dey TK. Text Book of Pathology. New Central Book Agency (P) Ltd, New Delhi, 2003.
Farooqi, Akbar, Sheikh, Nikhat, Muqaddam, Mushtaq. Evaluation of efficacy of Unani compound formulation Saffofe Hissat in the management of Hissatul Kulliya (nephrolithiais). National medicos. 18.2 (2012):15-18.

Finlayson, Birdwell. Physiochemical Aspects of Urolithiasis. Kidney International, 13(1978): 344-360.

Haddad, Farid Sami. Highlights on the history of medicine in the Middle East. T. Klin J. Med. Ethics, Law and History. 10 (2002): 243-257.

Ibn, Rushd. Kitāb Al-Kulliyāt (Urdu). Central Council for Research in Unani Medicine, New Delhi: (1987): 224227.

Israili, A. H. Humoral theory of Unani Tibb. Indian Journal of History of Science, 16.1 (1981): 95-99.

Jurjān̄̄, Ismā‘̄̄l. Tarjuma-i Zakhira-i Khwārzam Shāhī (Urdu translation by H. H. Khan). Munshi Naval Kishore Press, Lucknow. 1903 Vol. 2.

Kabiruddin, Hakim Muhammad. Bayad-i Kab̄̄r (Urdu). Siddique publication, Lahore (undated). Vol 1: 168170

Kabiruddin, Hakim Muhammad. Al- Iksīr (Urdu). Ejaz Publication House, Delhi, 2003, Vol 2.

Kumar, Rajesh. Study of Hișat-i Kulliya (renal calculus) with therapeutic evaluation of Unani formulation in its management. Thesis submitted to Rajiv Gandhi University of Health sciences, Bangalore. 2011

Madineh, Seyed Muhammad Ali. Avicenna's Canon of Medicine and Modern Urology. Part I: Bladder and its diseases. Urological Journal, 5 (2008): 284-293.

Al-Majūs̄̄, Ibn 'Abbās. Tarjumā-i Kāmilus Sanā' (Urdu Trans. by Ghulam Hussain Kantoori), Vol. 1\&2. 1889.

Al-Mașīhī, Ibn Al-Qaff. Kitāb Al-Umda fi'l Jarāhat. Central Council for Research in Unani Medicine, New Delhi;(1986): Vo1 2: 235-238.

Mohan H. Text Book of Pathology. Jaypee Brothers Medical Publication (P) Ltd, New Delhi, 2000

Rāzī, Zakariyya, Al-Hāầ (Urdu). Central Council for Research in Unani Medicine, New Delhi, Vo1. 10, 2002.

Rāzī, Zakariyya. Kitāb Al-Mansūri (Urdu). Central Council for Research in Unani Medicine, New Delhi, 1991.

Salam, M. A. Principles and Practice of Urology - A Comprehensive Text. Brown Walker Press, Parkland. FL. USA. Vol. 1, 2003. 